\title{
Environmental DNA metabarcoding uncovers environmental correlates of fish communities in spatially heterogeneous freshwater habitats
}

\author{
Petr Blabolil ${ }^{1}$, Lynsey Harper ${ }^{2}$, Stepanka Ricanova ${ }^{1}$, Graham Sellers ${ }^{2}$, Cristina Di Muri ${ }^{2}$, \\ Tomáš Jůza ${ }^{1}$, Mojmír Vašek ${ }^{1}$, Zuzana Sajdlová ${ }^{1}$, Pavel Rychtecký ${ }^{1}$, Petr Znachor ${ }^{1}$, Josef \\ Hejzlar $^{1}$, Jiří Peterka ${ }^{1}$, and Bernd Haenfling ${ }^{2}$ \\ ${ }^{1}$ Biology Centre CAS, Institute of Hydrobiology \\ ${ }^{2}$ University of Hull
}

June 22, 2020

\begin{abstract}
Biomonitoring of complex heterogeneous environments is highly challenging. Fish in deep water bodies occupy different habitats, therefore a combination of survey methods has traditionally been used. Environmental DNA (eDNA) metabarcoding is a novel monitoring tool that can overcome spatial heterogeneity in a highly sensitive and entirely non-invasive manner. However, taxon detection probability is dependent on real-time environmental variables. In this study, three reservoirs were sampled in two seasons using a spatiotemporally distributed sampling design covering major environmental gradients. In all sampling campaigns, 31 fish taxa were detected which exceeded expectations. Data reliability was confirmed by a tight positive correlation between individual taxon scores derived from gillnet sampling and eDNA site occupancy. Analyses confirmed anticipated trends, such as the highest number of taxa were observed in the largest water body, and more taxa were detected in inflows and littoral regions compared to open water. The most important factors for fish distribution were temperature, age and trophic status (expressed as total Chlorophyll a concentration) of water bodies. Taxon detection reflected ecological niches of individual species, e.g. warm water wels catfish (Silurus glanis) and cold water salmonids. This study provides further evidence that eDNA metabarcoding is suitable for ecological study in heterogeneous environments and may substitute conventional fish sampling techniques.
\end{abstract}

\section{Introduction}

High quality water sources are essential for ecosystem service provisioning under global change, including climate and pollution (Baron et al., 2002). One effective way to maintain high quality water sources is water storage in reservoirs that have been created for drinking, agriculture and industrial purposes, flood protection, recreation, and hydropower generation among others (Labadie 2004). Despite the key importance of reservoirs, research has typically focused on natural water bodies whereas artificial or heavily modified water bodies are often neglected (Straškraba 2005). Deep reservoirs are prime, widespread examples of aquatic heterogeneous ecosystems with hydrological characteristics that are intermediate between lakes and rivers, and include lacustrine, transitional and riverine components (Wetzel 2001).

Deep temperate reservoirs are hydrologically complex environments where seasonal variation in temperature and flow conditions affects stratification and mixing patterns of the water column. River inflows along with an intricate outflow dam system further modify reservoir hydrodynamics and often result in currents and intrusion of water to deeper strata (Ford, 1990, Straškrabová et al., 1994). In summer, stable thermal stratification occurs with higher temperature $\left(>20{ }^{\circ} \mathrm{C}\right)$ in the epilimnion and lower temperature $\left(4{ }^{\circ} \mathrm{C}\right)$ 
associated with higher water density in the hypolimnion. Summer stratification is followed by autumn mixing of the entire water column, with gradual cooling to temperatures around or below $4{ }^{\circ} \mathrm{C}$. During winter, the hypolimnion contains water of the highest density with temperature close to $4{ }^{\circ} \mathrm{C}$, and surface water has lower density with possible ice coverage. The stability of the water column in winter depends on weather conditions (e.g. ice cover, wind, precipitation) and water level manipulations. In canyon-shaped reservoirs, spatial heterogeneity is also associated with longitudinal gradients (Thornton et al., 1990). Nutrient rich tributaries support phytoplankton production, which decreases towards the dam (Rychtecký \& Znachor, 2011). A transition between the littoral and pelagic zones represents an additional source of reservoir spatial heterogeneity as the littoral zone differs in many aspects from more homogeneous pelagic habitats (Říha et al., 2015). Littoral habitats can be complex with macrophyte, rock and root configurations, or simple (e.g. sandy or muddy beaches), creating diverse environments affecting species composition, abundance and spatial distribution of the whole trophic web, from phyto- and zooplankton to fish (Prchalová et al., 2009a).

Fish have both direct and indirect effects on all trophic levels and are well-adapted to the various environmental conditions of heterogeneous temperate freshwaters. Therefore, they are often used as ecological indicators (EC, 2000). The long lifespan of many species also means that fish communities reflect changes over decadal timescales (Blabolil, et al., 2017b). Reliable assessment of fish community composition in reservoirs has typically required a combination of various sampling methods. However, established sampling methods are relatively laborious, expensive, sometimes destructive, taxonomically biased, and their application is case-specific, thus these limitations often result in poor accuracy and precision (Kubečka et al., 2009). In Europe, gillnetting is commonly used to assess fish populations, but this type of fish survey is extremely invasive (Blabolil, et al., 2017a). Therefore, efforts should be invested in the implementation of less-invasive and more universal monitoring strategies. Traditionally, visual census and hydroacoustics have been used for non-invasive surveys, but both have limitations. The accuracy of visual census depends on water clarity (Holubová et al., 2019), whereas hydroacoustics application is constrained by water depth and results do not provide species composition (Baran et al., 2017). Recently, environmental DNA (eDNA) metabarcoding has come to the fore as an innovative method for aquatic biodiversity biomonitoring (Taberlet et al., 2018).

eDNA refers to genetic material released by organisms into their environment, which can be captured and analyzed to enable non-invasive, highly sensitive species detection (Taberlet et al., 2018). Aquatic ecosystems are particularly suited to eDNA analysis as water is an effective medium for deposition and transport of intracellular or extracellular organismal DNA from aquatic, semi-aquatic and terrestrial organisms (Deiner et al., 2016; Harper et al., 2019b). All water bodies can be easily sampled to collect eDNA, including temporary pools (Bylemans et al., 2019), rivers (Deiner et al., 2016), ponds (Harper et al., 2019a), large heterogeneous lakes (Lawson Handley et al., 2019) and marine environments (Djurhuus et al., 2020). eDNA metabarcoding is an especially powerful and cost-efficient approach for biomonitoring as it allows whole communities to be screened (Hering et al., 2018). During metabarcoding, eDNA is PCR-amplified using broad-range primers and sequenced on a high-throughput sequencing platform (Deiner et al., 2017). However, species composition and distribution inferred from eDNA metabarcoding must account for environmental conditions that influence eDNA dynamics. Various factors affect eDNA persistence and degradation, such as temperature, ultraviolet (UV) light intensity, and oxygen concentration, that in turn determine microbial action and metabolic activity of aquatic organisms (Barnes et al., 2014). The spatial distribution of eDNA in a given water body can be influenced by species' habitat preferences and activity (de Souza et al., 2016), oxygen and trophic conditions (Lawson Handley et al., 2019), or water movements caused by inflows and outflows, precipitation, wind, convective currents etc. (Jeunen et al., 2019). Background data characterizing environmental conditions and their possible links to eDNA dynamics are desperately needed, but are often not provided in published studies (Nicholson et al., 2020; Ruppert et al., 2019).

The aim of our study was to use eDNA metabarcoding to assess the fish communities in three Czech Republic reservoirs across two seasons. We compared species composition at multiple sites characterizing the spatial gradient in each of the reservoirs. We also tested the relationship between eDNA site occupancy and scores derived from conventional sampling for each taxon. Finally, we analyzed the relationship between species diversity and reservoir spatial heterogeneity. 


\section{Materials and Methods}

Study sites

We selected three reservoirs in the Czech Republic of different trophic status (from eutrophic Rímov to oligotrophic Klíčava), size and hydrodynamics (Table 1). All reservoirs possess canyon-shape morphology with one main inflow (Figure 1), resulting in longitudinal gradients of nutrients and water quality from the inflow to the dam. In summer, the water column is thermally stratified followed by water mixing in late autumn. All studied reservoirs serve as drinking water storages and are therefore restricted to public access. Fish communities are dominated by cyprinids (mainly bleak [Alburnus alburnus], freshwater bream [Abramis brama ], roach [Rutilus rutilus]) in Ř́mov and Žlutice, and by European perch (Perca fluviatilis ) in Klíčava despite regular stocking of piscivorous species, i.e. asp (Leuciscus aspius), Northern pike (Esox lucius), pikeperch (Sander lucioperca), wels catfish (Silurus glanis ) (Vašek et al., 2013).

\section{eDNA sampling and environmental parameters}

In order to cover the expected spatial heterogeneity within reservoirs, samples were collected at intervals of approximately $1 \mathrm{~km}$ along the river channel, hereafter referred to as "localities". Based on the length of the river basin, five localities were sampled in Klíčava and Žlutice, and eight localities were sampled in Římov. In each reservoir, one more locality was sampled in a side basin (Figure 1). At each locality, samples were collected at both banks in the littoral zone and from the surface layer of the pelagic zone, approximately halfway between the two littoral samples. Additional deep water samples were collected along a vertical transect $5 \mathrm{~m}, 10 \mathrm{~m}$ and $20 \mathrm{~m}$ at all pelagic sites in Klíčava and Žlutice, and at localities 1, 4, 6 and the side basin in Rímov. The number of pelagic samples taken depended on water depth at each site (Figure 1). A single sample each was collected from the inflows to the main reservoirs and the side basins respectively. Littoral, pelagic (depth separated), and inflow samples are hereafter referred to as "habitats". Each site was sampled twice, with sampling campaigns in the summer and late autumn of 2018 (Table 2). During the Klíčava and Žlutice summer campaigns, samples from $5 \mathrm{~m}$ depth in the bay were not collected. During the late autumn campaign in Ř́mov, locality 8 (closest to the main tributary) was covered with ice preventing water sample collection. The total number of samples collected in summer/late autumn was 29/30 in Klícava, $38 / 35$ in Římov and 28/29 in Žlutice.

At each locality, $2 \mathrm{~L}$ of water was sampled by pooling five $400 \mathrm{~mL}$ subsamples taken within $50 \mathrm{~m}$ of the locality. A Friedinger sampler (Karel Šramhauser - Plastické hmoty, CZ) was used for water collection. To avoid excessive seston, the water samples were pre-filtered in the field with a $40 \mu \mathrm{m}$ sterile plankton net into sterile plastic bottles that were placed in an isolated box with ice for storage at approximately $4{ }^{\circ} \mathrm{C}$ until further processing. Sampling equipment was sterilized by soaking for $10 \mathrm{~min}$ in $10 \%$ commercial bleach solution (containing 5\% sodium hypochlorite), followed by soaking for $10 \mathrm{~min}$ in $10 \%$ microsol detergent solution and rinsing with purified water between localities. The sampler was then rinsed again in reservoir water at the next locality. After water sample collection, field blanks (0.5 L purified water per sampling campaign) were passed through the sampler, then passed through a sterile plankton net back into the storage bottle.

Meteorological conditions (i.e. air temperature, wind speed and cloud cover), water inflow and water level were measured during each sampling event by a floating tower (Aquaread, UK) with multiparametric sensors (Fiedler, CZ) in the dam section of each reservoir. At each pelagic locality, vertical profiles of water temperature and concentration of dissolved oxygen (DO) were measured using a multiparameter probe YSI EXO II (YSI, USA). Chlorophyll a (ChlA) concentrations of four phytoplankton groups (i.e. green algae, diatoms, cyanobacteria and cryptomonads) were measured by the bbe Moldaenke FluoroProbe GmbH.

The field sampling and experimental protocols were performed in accordance with the guidelines and permission from the Experimental Animal Welfare Commission under the Ministry of Agriculture of the Czech Republic (Ref. No. CZ 01679) and the experimental project was approved by the Ministry of Environment of the Czech Republic (Ref. No. MZP/2019/630/16). All methods were approved by the Experimental Animal Welfare Commission of Biology Centre of the Czech Academy of Sciences. 


\section{eDNA capture and extraction}

All samples were filtered within 24 hours of collection in a decontaminated laboratory (bleached floors and surfaces) that is not used for handling fish specimens or DNA. We filtered $1 \mathrm{~L}$ of each sample $(2 \times 0.5 \mathrm{~L})$ through two sterile mixed cellulose acetate and cellulose nitrate filters $(47 \mathrm{~mm}$ diameter, $0.45 \mu \mathrm{m}$ porosity, Whatman, UK) using Nalgene filtration units in combination with a vacuum pump. The filters were folded using sterile tweezers, placed in $1.5 \mathrm{~mL}$ Eppendorf tubes filled with $96 \%$ ethanol, and stored in the dark at $4{ }^{\circ} \mathrm{C}$. Filtration equipment was sterilized in $10 \%$ commercial bleach solution for $10 \mathrm{~min}$, followed by soaking for $10 \mathrm{~min}$ in $10 \%$ microsol solution, and rinsed with purified water after each filtration round. Field blanks also served as filtration blanks, that were run before the first filtration round, during filtration, and after the last filtration round to monitor potential contamination.

In March 2019, the filters in ethanol were transported at room temperature (six days) to a dedicated eDNA facility at the University of Hull. In a UV and bleach sterilized laminar flow hood, filters were removed from ethanol onto individual sterile Petri dishes to dry for approximately $30 \mathrm{~min}$. Dry filters from the same sample were transferred to a $5 \mathrm{~mL}$ screw cap tube (Axygen, Fisher Scientific, UK). The storage ethanol was transferred to a sterile $1.5 \mathrm{~mL}$ Eppendorf tube and centrifuged for $40 \mathrm{~min}$ at 11,000 x g. The supernatant was discarded and the dry pellet dissolved in $50 \mu \mathrm{L}$ molecular grade water. The eluate was added to the appropriate $5 \mathrm{~mL}$ screw cap tube containing dry filters. For each sampling campaign, two sterile filters washed with $99 \%$ ethanol were processed alongside sample filters to act as evaporation blanks and monitor possible contamination. All dried filters were stored at $-20{ }^{\circ} \mathrm{C}$ for one week until DNA extraction.

DNA was extracted following the Mu-DNA water protocol (Sellers et al., 2018). A subset of samples were initially extracted to test extraction protocol efficacy. Based on relatively low DNA concentrations (average $7.7 \mathrm{ng} / \mu \mathrm{L}$ ) measured by NanoDrop 1000 Spectrophotometer, the original protocol was modified to increase DNA yield. The volumes of lysis solution and water lysis additive were increased to $900 \mu \mathrm{L}$ and $300 \mu \mathrm{L}$ respectively. To enhance lysate yield, the centrifugation step was extended to $2 \mathrm{~min}$, and all lysate was transferred to a sterile tube with flocculant solution for the inhibitor removal step. Finally, the eluate was transferred back onto the spin column membrane, incubated at room temperature, and centrifuged to increase DNA yield. To minimize contamination risk between reservoirs, DNA extraction was performed separately for each sampling campaign. DNA was extracted from all filters, field/filtration blanks, evaporation blanks, and extraction blanks (i.e. extraction buffers only) for each sampling campaign. An extraction blank was included for each batch of extractions (two per sampling campaign), that were subsequently pooled to provide one extraction blank for each sampling campaign. Extracted DNA was stored at $-20{ }^{\circ} \mathrm{C}$ for one week until PCR amplification.

\section{eDNA metabarcoding}

The sequencing library was generated from PCR amplicons produced using the primer pair 12S-V5-F ( $5^{\prime}-$ ACTGGGATTAGATACCCC-3') and 12S-V5-R (5'-TAGAACAGGCTCCTCTAG-3'), which amplifies a 73-110 bp fragment of the mitochondrial 12S ribosomal RNA (rRNA) gene in vertebrates (Riaz et al., 2011), and a 106 bp fragment in European fishes (Hänfling et al., 2016). All PCRs were set up using eight-strip PCR tubes in a UV and bleach sterilized laminar flow hood in the eDNA laboratory to minimize contamination risk. To detect possible PCR contamination within each sub-library, we included PCR negative controls (molecular grade water) and PCR positive controls. The latter used tissue DNA $(0.05 \mathrm{ng} / \mu \mathrm{L})$ from Zebra mbuna (Maylandia zebra), a cichlid from Lake Malawi which is not present in natural waters in the Czech Republic. The locus primers were attached to 24 unique index combinations and heterogeneity spacers for the first PCR. The first PCR for each sample, field/filtration blank, evaporation blank, extraction blank, PCR negative control and PCR positive control was performed in $25 \mu \mathrm{L}$ reaction volumes, including $12.5 \mu \mathrm{L}$ Q5 ${ }^{\circledR[}{ }^{[?]}$ High-Fidelity $2 X$ Master Mix (New England Biolabs ${ }^{(\mathrm{r})}$ Inc., MA, USA), $1.5 \mu \mathrm{L}$ of each primer $(10 \mu \mathrm{M}$, Integrated DNA Technologies), $0.5 \mu \mathrm{L}$ Thermo Scientific Bovine Serum Albumin (Fisher Scientific, UK), 5 $\mu \mathrm{L}$ DNA, and $4 \mu \mathrm{L}$ molecular grade water. PCR conditions were initial denaturation for 5 min at $98{ }^{\circ} \mathrm{C}$, 35 cycles of $10 \mathrm{~s}$ at $98{ }^{\circ} \mathrm{C}, 20 \mathrm{~s}$ at $58{ }^{\circ} \mathrm{C}$ and $30 \mathrm{~s}$ at $72{ }^{\circ} \mathrm{C}$, and final extension for $7 \mathrm{~min}$ at $72{ }^{\circ} \mathrm{C}$. Three technical replicates were performed for each sample and then pooled to minimize PCR stochasticity. Pooled 
PCR products were visualized on a $2 \%$ agarose gel stained with GelRed (Cambridge Bioscience, UK). PCR products were normalized into 12 sub-libraries (two per sampling campaign) based on the band strength observed for each sample (very bright $=5 \mu \mathrm{L}$, bright $=10 \mu \mathrm{L}$, faint $=15 \mu \mathrm{L}$, and very faint/no band $=$ $20 \mu \mathrm{L}$ ) together with $10 \mu \mathrm{L}$ of the filtration blanks, evaporation blanks, extraction blanks, PCR negative controls and $1 \mu \mathrm{L}$ of the PCR positive controls (Alberdi et al., 2018). The normalized sub-libraries were purified using a double size selection protocol with Mag-Bind@ TotalPure NGS magnetic beads (Omega Bio-tek, USA) to remove primer dimers and large secondary products (Bronner et al., 2014). Ratios of 0.9× and $0.15 \times$ magnetic beads to $100 \mu \mathrm{L}$ of each sub-library were used.

The 12 purified sub-libraries were used as template DNA for a second PCR attaching Illumina indices. The second PCR was performed in $50 \mu \mathrm{L}$ reaction volumes, consisting of $25 \mu \mathrm{L}$ Q $5^{\circledR[}{ }^{[?]}$ High-Fidelity $2 \mathrm{X}$ Master Mix, $3 \mu \mathrm{L}$ of each primer $(10 \mu \mathrm{M}), 4 \mu \mathrm{L}$ purified product, and $15 \mu \mathrm{L}$ molecular grade water. PCR conditions were initial denaturation for $3 \mathrm{~min}$ at $95{ }^{\circ} \mathrm{C}, 10$ cycles of $20 \mathrm{~s}$ at $98{ }^{\circ} \mathrm{C}$ and $1 \mathrm{~min}$ at $72{ }^{\circ} \mathrm{C}$, and final extension for 5 min at $72{ }^{\circ} \mathrm{C}$. PCR was performed for sub-libraries in duplicate and replicates were pooled before visualization on a $2 \%$ agarose gel stained with GelRed. The sub-libraries were purified using a double size selection protocol with magnetic beads to remove secondary products (Bronner et al., 2014). Ratios of $0.7 \times$ and $0.15 \times$ magnetic beads to $50 \mu \mathrm{L}$ of each sub-library were used. The sub-libraries were normalized and pooled according to the number of samples each contained (without blanks and PCR negative controls) and their DNA concentration. The pooled library was purified again using the same volumes and ratios as the previous purification, and quantified by qPCR using the NEBNext ${ }^{\circledR}$ Library Quant Kit for Illumina ${ }^{\circledR}$ (New England Biolabs ${ }^{\circledR}$ Inc., MA, USA) on a StepOnePlus Real-Time PCR System (Thermo Fisher Scientific, UK) following manufacturer's guidelines. Removal of secondary product was verified using an Agilent 2200 TapeStation and High Sensitivity D1000 ScreenTape (Agilent Technologies, CA, USA). Libraries were run at $13 \mathrm{pM}$ with $10 \%$ PhiX Control v3 on an Illumina MiSeq $^{(\mathrm{r})}$ using a MiSeq Reagent Kit v3 (600-cycle) (Illumina, Inc., CA, USA).

\section{Bioinformatics analysis}

Raw sequence reads from the Illumina MiSeq were evaluated using FASTQC (http:// www.bioinformatics.babraham.ac.uk/projects/fastqc). Raw sequence reads were demultiplexed using a custom Python script before bioinformatic processing using metaBEAT v0.97.11 (https://github.com/HullUnibioinformatics/metaBEAT), which is a custom pipeline that incorporates commonly used open source software. The program Trimmomatic 0.32 (Bolger et al., 2014) was used for quality trimming and removal of locus primers from the raw sequence reads. Average read quality was assessed in 5-bp sliding windows starting from the 3' of the read, and reads were clipped until the average quality per window was above phred 30. All reads shorter than a defined minimum $90 \mathrm{bp}$ read length were discarded. Sequence pairs were subsequently merged into single high-quality reads using the program FLASH 1.2.11 (Magoč \& Salzberg, 2011). Reads surviving quality filtering and trimming were screened for chimeric sequences against a custom, curated reference database using the uchime_ref function implemented in vsearch 1.1 (https://github.com/torognes/vsearch). The reference database was developed at the University of Hull (Hänfling et al., 2016) and supplemented with asp (GenBank accession numbers: MT163435, MT163450, MT163449) and marena whitefish (Coregonus maraena) (GenBank accession numbers: MT163451, MT163458, MT163460) to represent all fish species in the study catchment. Sequences were clustered at $100 \%$ identity using VSEARCH v1.1. Clusters represented by less than three sequences were considered sequencing error and were omitted from further analysis. Nonredundant sets of query sequences were then compared to the reference database using BLAST (Zhang et al., 2000). BLAST output was interpreted using a custom python function, which implements a lowest common ancestor approach for taxonomic assignment, similar to the strategy used by MEGAN 5.10.6 (Huson et al., 2007). BLAST hits were only considered if they possessed a minimum identity of $99 \%$ and $90 \%$ query coverage.

\section{Data analysis}

A false positive sequence threshold $(0.1 \%)$ was applied to the metabarcoding inventory, where taxa recorded within each sample were discarded if their read frequencies fell below this threshold (Hänfling et al., 2016; 
Lawson Handley at al., 2019). The metabarcoding inventory was then checked for spurious taxa (i.e. taxa that do not occur in the Czech waters or occurred in very few samples), and taxonomic assignments were corrected. Capelin (Mallotus villosus ) was found in one reservoir sample and thus removed from downstream analyses. A number of species level taxonomic assignments lacked credibility and were reassigned to genus level. Sturgeon (Acipenser sturio ) was changed to Acipenser spp. as Siberian sturgeon (A. baerii) and Danube sturgeon (A. gueldenstaedtii ) were previously captured by conventional methods but these species were missing from our reference database. Vendace (Coregonus albula) was corrected toCoregonus spp. as maraena whitefish and peled (C. peled) are more often stocked in Czech waters. Similarly, Arctic char (Salvelinus alpinus ) was corrected to Salvelinus spp. as the closely related brook trout (S. fontinalis ) is more often stocked in Czech waters, and these species cannot be distinguished using the target $12 \mathrm{~S}$ rRNA fragment. Silver carp (Hypophthalmichthys molitrix) and bighead carp (H. nobilis ) were merged toHypophthalmichthys spp. as both species are artificially selected, resulting in hybrids, and share the same ecological niches. Finally, river lamprey (Lampetra fluviatilis ) was corrected toLampetra spp. because river lamprey is not present in the studied catchments and sequences likely belong to European brook lamprey $(L$. planeri ) which does not possess reference sequences. Four species that occur in the studied reservoirs were assigned to family level as they could not be distinguished using the target $12 \mathrm{~S}$ rRNA fragment. Asp and rudd (Scardinius erythrophthalmus) reference sequences were identical and assignments therefore corrected to Cyprinidae, and European perch and pikeperch were identical and corrected to Percidae. One species, Burbot (Lota lota), was completely missed by eDNA metabarcoding having been previously detected in Ř́mov with gillnetting. Excluding Cyprinidae and Percidae, higher taxonomic assignments (i.e. families, including Salmonidae, or higher ranks) were excluded from downstream analyses due to uncertainty and differing species' ecologies.

Remaining taxa were classified as non-native or according to the International Union for Conservation of Nature (IUCN) Red List categories (Lusk et al., 2017; Pergl et al., 2016). For each reservoir, five abundance categories were created (Table 3) based on previous ichthyological surveys using benthic and pelagic gillnets during the last 15 years (e.g. Blabolil, et al., 2017a). Species presence was also assessed by seining, electrofishing, fyke-nets, trawling (Jůza et al., 2015; Ríha et al., 2015), and expert judgment of FishEcU members (www.fishecu.cz).

Data on inflow, meteorological conditions and reservoir operation were used as input variables in the CEQUAL-W2 model (Wells, 2019) to compute hydrodynamics, age of water along the longitudinal and vertical profile of reservoirs (i.e. a model variable that is used to estimate the residence time, which accumulates at a rate of $1.0 \mathrm{~d}^{-1}$ with all new water entering the system having an age of zero, Monsen et al., 2002) and real-time environmental parameters during sampling campaigns. Measured water parameters were plotted using Surfer software (Surfer 9, Golden Software Inc.). The ChlA concentration data were log-transformed to achieve a normal data distribution. The water age data were normalized within the range from $0-1$ for each reservoir to evaluate the proportion of fresh inflow water within each reservoir locality.

Site occupancy and regression analyses were conducted in R v.4.0.0 (R Development Core Team, 2020). We calculated sample-based site occupancy estimates for each taxon (i.e. number of positive samples divided by total number of samples, without inflows) as a proxy for relative abundance in the main reservoir body. A Generalized Linear Mixed-effects Model (GLMM) with reservoir identity as a random effect was applied to test the difference in the number of taxa between the main and side tributaries and in the main reservoir. A second GLMM with reservoir identity as a random effect was used to test the difference in the number of taxa between localities, habitats and seasons. Bray-Curtis dissimilarity for samples taken in the same reservoir, season and habitats was computed using the vegdist function in the package vegan (Oksanen et al., 2019). Differences in Bray-Curtis dissimilarity between sites were compared using a GLMM with habitat and sampling season as fixed effects and reservoir identity as a random effect. Spearman's rank correlation coefficient was used to test the relationship between eDNA-based site occupancy and the taxon score derived from gillnet sampling. Differences in the number of taxa for each reservoir between season and correlation coefficients for different seasons were compared using a paired t-test. 
Multivariate analyses were performed in CANOCO 5 software (Šmilauer \& Lepš, 2014). We tested whether fish communities in each reservoir (without inflows) were influenced by environmental variables using a Constrained Canonical Correlation Analysis (CCA). Relationships between fish taxa in the main reservoir body and temperature, DO concentration, total ChlA concentration, normalized water age, locality and habitat were tested using a CCA Interactive Forward Selection with the covariable reservoir identity while restricting the permutations. Log-transformed read counts were supplied to a Monte-Carlo permutation test with 9999 permutations using a test of significance on all constrained axes.

\section{Results}

\section{Environmental parameters}

In summer, precipitation and inflow were lower than in late autumn (Table 2). The air temperature was consistent with the temperate region, wind was low and cloud cover variable with no or limited precipitation in summer. In autumn, low precipitation was observed before the sampling campaigns (Table 2). The water level decreased by approximately $1.0 \mathrm{~m}$ in Klíčava and Římov and by $2.2 \mathrm{~m}$ in Žlutice between the summer and autumn sampling campaigns (Table 2). In all reservoirs, stable thermal stratification was established in summer when the surface water temperature exceeded $20{ }^{\circ} \mathrm{C}$. In late autumn, surface water temperature was on average $6{ }^{\circ} \mathrm{C}$ and thermal stratification eroded (Supplementary Figure 1). The vertical distribution profiles of oxygen during summer differed between the three reservoirs. In Klíčava, a positive heterograde profile with a maximum oxygen concentration in the metalimnion (middle layer) and anoxic hypolimnion (deep layer) was observed. In contrast, a negative heterograde profile with a metalimnetic minimum and anoxic deep layers characterized oxygen stratification in Rímov. In Žlutice, a clinograde oxygen profile with the maximum in the epilimnion (surface layer) and anoxic deep strata was observed (Supplementary Figure 2). In late autumn, the hypolimnetic layers remained anoxic in Klíčava and Římov, where weak thermal stratification persisted. Klíčava had the lowest ChlA concentration with summer maxima in the metalimnion (Supplementary Figure 3). In the other two reservoirs, inflowing nutrients resulted in high summer ChlA concentrations in the upstream parts (Supplementary Figure 3). The longest water age was in Klíčava (¿2 years), with little water exchange and complete mixing of inflow within the reservoir in the tributary zone (Supplementary Figure 4). The shortest water age was in Rímov, where river water was directed above the metalimnetic layer and mixed with the epilimnion in summer, but in autumn river water was vertically mixed into the whole water column supplying flowing fresh water along the longitudinal reservoir profile (Supplementary Figure 4). The water age in Žlutice shows that the inflow mixed extensively with the epilimnetic layer in summer and the reservoir was mostly homogeneous in autumn (Supplementary Figure 4).

\section{eDNA metabarcoding}

The $12 \mathrm{~S}$ library generated 22.46 million raw sequence reads, with 13.51 million reads passing bioinformatic filters. After quality filtering and removal of chimeric sequences, each reservoir sample contained 63,593 target reads (i.e. fish) on average. Zebra mbuna was the only fish species detected in PCR positive controls. In negative controls (field/filtration blanks, evaporation blanks, extraction blanks, and PCR negative controls), no fish species were detected.

\section{Diversity and site occupancy of fish communities}

Altogether 30 bony fish taxa and one lamprey were identified in the 189 reservoir samples (Table 4, Figure 2). Across the dataset (i.e. all reservoirs and seasons), no fish were detected in nine pelagic and two littoral samples. Six taxa were detected in all reservoirs and seasons, and another 14 taxa were consistently detected in the same reservoir in summer and autumn. Conversely, six taxa were only detected in one sampling campaign (Table 4). Seven taxa were categorised as non-native and others were sorted in six IUCN categories from Extinct, Critically Endangered, and Vulnerable, to Least Concern (Table 4).

Ŕímov possessed the most taxa whereas Klíčava had the lowest number of taxa (Figure 3). In all reservoirs, significantly more taxa were detected in late autumn compared to summer $\left(\mathrm{t}_{2}=12.124, \mathrm{p}=0.007\right)$ (Figure 
3). The Spearman's rank correlation coefficient between site occupancy and gillnet score for each taxon was statistically significant for all sampling campaigns (Figure 5, p i 0.05). The rho correlation coefficients were higher in summer than in late autumn, but this was not statistically significant due to low sample size $\left(\mathrm{t}_{2}\right.$ $=1.981, \mathrm{p}=0.186)$.

More taxa per sample were detected in the main inflows than in the side tributaries (GLMM: $\mathrm{F}_{3,6}=6.458, \mathrm{p}$ $=0.026)$ and in the main reservoirs (GLMM: $\left.\mathrm{F}_{3,177}=11.918, \mathrm{p} ; 0.001\right)$. Differences in the number of taxa between samples from the reservoirs and the side tributaries were not significant (GLMM: $\mathrm{F}_{3,177}=0.327$, $\mathrm{p}=0.806$ ) (Figure 3). In the main body of the reservoirs, the number of taxa was significantly different between localities showing an increasing trend from the dam to the tributary (GLMM: $\mathrm{F}_{3,171}=14.473, \mathrm{p}$ $i$ 0.001). Moreover, the in-reservoir habitats differed in the number of taxa with highest diversity in the littoral zone (GLMM: $\mathrm{F}_{12,162}=2.128, \mathrm{p}=0.017$ ) and without a significant seasonal effect (GLMM: $\mathrm{F}_{3,171}$ $=0.946, \mathrm{p}=0.420)$ (Figure 2, 3). The Bray-Curtis dissimilarity indices were significantly different between habitats (GLMM: $\left.\mathrm{F}_{5,723}=21.104, \mathrm{p} ; 0.001\right)$ and seasons (GLMM: $\mathrm{F}_{1,722}=27.689$, $\left.\mathrm{p} ; 0.001\right)$ (Figure 4).

\section{Environmental correlates of fish distribution}

Temperature (whole CCA test: $4.4 \%$ of explained variability, pseudo-F $=7.0, \mathrm{p}<0.001$ ), normalized water age (whole CCA test: $3.7 \%$ of explained variability, pseudo-F $=6.0, \mathrm{p}<0.001$ ) and ChlA (whole CCA test: $1.2 \%$ of explained variability, pseudo-F $=1.9, \mathrm{p}<0.001$ ) were significant environmental variables selected by Interactive Forward Selection procedure (Figure 6a, b). The first axis explained $7.07 \%$ of the variation, whereas the second and third axes explained $1.53 \%$ and $0.65 \%$ of the variation, respectively. Based on the ordination score, the first axis is mostly correlated with temperature, where some taxa prefer high temperature (e.g. pumpkinseed [Lepomis gibbosus ], wels catfish), some taxa are flexible (e.g. bleak, freshwater bream, white bream [Blicca bjoerkna], roach, ruffe [Gymnocephalus cernua]), and other taxa prefer cold water (e.g. all salmonids, bullhead [Cottus gobio ], Coregonus spp., Lampetra spp., stone loach [Barbatula barbatula], topmouth gudgeon [Pseudorasbora parva]). The second axis was predominantly correlated with normalized water age, separating taxa detected in the deep lacustrine part with longer retention time (e.g. prussian carp [Carassius auratus gibelio ]) from those detected near the river inflows (e.g. bullhead, Coregonus spp., grayling [Thymallus thymallus ], gudgeon [Gobio gobio ],Lampetra spp., stone loach). Finally, the third axis correlated with the proxy of the trophic gradient, with European eel (Anguilla anguilla), pumpkinseed and wels catfish detection in more trophic habitats, and prussian carp and Coregonus spp. detected in nutrient-low environments.

\section{Discussion}

Our study demonstrates that eDNA metabarcoding is a useful tool for the assessment of fish diversity in spatially heterogeneous temperate water bodies. This novel molecular approach can be used to provide baseline data for reliable and sustainable long-term monitoring of these systems. The studied reservoirs exemplify heterogeneous water bodies with pronounced environmental gradients affecting spatial distribution of organisms that is not easy to capture with conventional monitoring methods. In this study, weather conditions during sample collection were typical for temperate regions, with a hot dry summer followed by cold wet autumn. The morphology of the studied reservoirs is similar, but their trophic status and hydrodynamics are different. However, despite such complex background variation, similar ecological relationships between biological and environmental factors were detected in different water bodies. Our results can therefore be used as an example of the applications for other heterogeneous systems.

\section{False positives and negatives}

Long-term fish surveys of the studied reservoirs provided robust background data on the expected distribution and abundance of individual species that allows these reservoirs to serve as models to study the mechanisms underlying spatial fish distribution. Gillnets are most commonly used to sample fish despite their invasiveness, size- and species-selectivity (Blabolil et al., 2016). Plentiful long-term (Znachor et al., 2020) and detailed spatially-resolved seasonal data (Rychtecký \& Znachor, 2011) as well as gillnet data dating back to 2004 (Blabolil, et al., 2017b; Říha et al., 2015) are available for Římov. Klíčava was intensively stud- 
ied for decades after dam building (Straškrabová \& Pivnička, 2001), and together with Žlutice, is studied for current ichthyological research interests (e.g. Vejř́k et al., 2019). Three and five gillnet campaigns in Klíčava and Žlutice respectively are supported by data from other sampling methods (i.e. electrofishing, fyke-nets, seining, hook lines and trawling) as well as expert knowledge about fish-habitat relationships (Blabolil et al., 2017b) All of these reservoirs are also routinely monitored by the Vltava River authorities for water chemistry and biological parameters (www.pvl.cz).

Based on expert knowledge and long-term monitoring of these reservoirs and their fish fauna, only a single taxon was identified as a clear false positive. Capelin, a marine fish of the North Atlantic, is likely environmental contamination, possibly through the use of Northern pike bait. No target fish DNA was found in the PCR positive and negative controls or the field/filtration, evaporation, and extraction blanks, which indicates that the field and laboratory protocols used were effective in avoiding contamination. Only one species, burbot, was previously observed in Rímov (last caught in spring 2011) and not detected by eDNA metabarcoding. Burbot is the only member of the family Gadidae in Czech waters, therefore misclassification is highly improbable. However, rarer eDNA templates are more likely to be missed during water sampling or lost during molecular workflow processing (Kelly et al., 2019). Burbot is active in cold water, thus eDNA sampling in winter or early spring may improve detection (Blabolil et al., 2018). We performed three PCR replicates per sample in order to reduce stochastic variation, but greater replication may have increased detection probability of rare species within individual samples (Harper et al., 2019b).

Some fishes, such as asp and rudd or European perch and pikeperch, belong to different genera, but sequences amplified using the 12S-V5 primers were identical. These species pairs were excluded from downstream analyses because of assignment uncertainty and differing ecologies, i.e. piscivorous asp and pikeperch preferring open water, and invertivorous European perch and omnivorous rudd preferring structured habitats (Blabolil et al., 2016, 2017a, 2017b). Taxonomic coverage, resolution, and accuracy could be improved for these and other genetically similar taxa (e.g. sturgeons and coregonids) by using different or additional primers that target bony fish, such as MiFish (Miya et al., 2015) and Teleo (Valentini et al., 2016). For taxonomic assignment, we used BLAST at 99\% identity against a reference database for UK fishes (Hänfling et al., 2016) that was supplemented with sequences for missing Czech fishes. Reference databases should ideally comprise sequences from specimens occurring in the study area for all species to account for potential phylogeographic variation as species can be locally adapted (Delrieu-Trottin et al., 2019). With a more comprehensive reference database, it may be possible to use $100 \%$ BLAST identity for taxonomic assignment.

\section{Diversity and site occupancy of fish communities}

The identification of 31 taxa by eDNA metabarcoding represented more taxa than expected. Higher fish detectability by eDNA metabarcoding compared to conventional methods has been found in riverine as well as lacustrine environments (Hänfling et al., 2016; Li et al., 2019a; McDevitt et al., 2019; Olds et al., 2016; Pont et al., 2018). In each reservoir, some taxa were detected for the first time by eDNA metabarcoding, demonstrating the sensitivity of this method.

All conventional methods (i.e. boat electrofishing, fyke-nets, gillnetting and seine netting) are selective, thus there are several reasons for species underestimation with these tools (Kubečka et al., 2009). Small-bodied species, such as European bitterling (Rhodeus amarus ) in Klíčava and stone loach in Žlutice, were most probably overlooked in structured benthic habitats. Even species with medium body size, such as white bream in Klíčava and Žlutice, could be misclassified to the more common freshwater bream with similar appearance (especially juveniles) or disguised as hybrids (Kottelat \& Freyhof, 2007). The other explanation is small population size in a water body and occurence in a specific habitat (Balasingham et al., 2017). Bullhead, Eurasian minnow (Phoxinus phoxinus) and salmonids are restricted to relatively small, structured and shallow parts of tributaries, which are difficult habitats to sample by conventional methods. Typically netting is used, but net diameters, mesh sizes and used material determine the catch (Prchalová et al., 2009b; Ríha et al., 2008). Large fish can escape from small nets or break through fragile nets, whereas small fish can escape through larger mesh sizes. Bleak, a common species in Rímov, was probably recently introduced in Žlutice (maybe with piscivorous fish stocking), as the first record in gillnets was in 2019 (Blabolil,pers. 
obs. ).

eDNA metabarcoding is acknowledged as a highly sensitive method for detection of invasive and endangered species (Lawson Handley, 2015). Of the seven non-native species we detected, prussian carp and topmouth gudgeon have invasive potential in the Czech Republic (Pergl et al., 2016). Spread of these species can be facilitated by outflowing water from ponds and therefore early and reliable detection is imperative to help protect native fishes. Pumpkinseed was detected only in main part of Rímov and will require immediate action to prevent further spread as it is naturally reproducing in the reservoir. Grass carp (Ctenopharyngodon idella ), Hypophthalmichthys spp., rainbow trout (Oncorhynchus mykiss ) and Salvelinus spp. are dependent on artificial stocking, but grass carp andHypophthalmichthys spp. are undesirable in reservoirs. Grass carp reduce submerged vegetation and Hypophthalmichthys spp. filter zooplancton in the water column, supporting phytoplankton. Therefore, early eDNA detection of undesirable species should trigger their elimination, similar to eradication management of common carp (Cyprinus carpio ) in Tasmania (Furlan et al., 2019) and topmouth gudgeon in the UK (Robinson et al., 2019).

Three taxa were classified as regionally Extinct as current populations are dependent on artificial stocking. Common carp is the most popular game fish in the Czech Republic and stocked in ponds across the country (Boukal et al., 2012). Ponds in catchments are the most probable source of individuals found in the studied reservoirs. Coregonus spp. and Acipenser spp. were detected only in Rímov. Ponds occur in this catchment as well as fish hatcheries breeding this species (Pstruhařství ČRS Kaplice, Ltd.) that are directly connected to the inflowing river. Potential escapees from pools is therefore plausible (Naylor et al., 2001). The European eel is categorised as Extinct in the Wild because migration of juveniles upstream is impossible and high mortality of adults during downstream spawning migration through dams with hydro turbines (Trancart et al., 2019). European eel eDNA detection in Klíčava and Římov could help initiate construction of suitable dam bypasses and/or capture of spawning stock and transport downstream past the dam.

The crucian carp (Carassius carassius ) was the only Critically Endangered species we detected and typically occurs in small ponds (Harper et al., 2019a), but here was exclusively detected from the side inflow to Rímov. In this particular case, it is very probable that eDNA originated upstream in a pool, the closest one being around $670 \mathrm{~m}$ from the sampling locality. This suggests that populations of endangered species could be identified through eDNA transport. Vulnerable taxa are rare in the reservoirs associated with tributaries (Eurasian minnow, grayling and Lampetra spp.) or submerged macrophytes (tench [Tinca tinca]), but these species can be considered as indicators of ecological quality and diverse habitats (Blabolil et al., 2017b, Šmejkal et al., 2014). The category of Near Threatened species is important as these species could be at high risk of extinction in the near future and therefore population assessment should follow any eDNA detections. Finally, most of the species we detected were classified as Least Concern, suggesting that conditions were suitable for common species.

The cumulative number of detected taxa was highest (29) in Ř́mov (largest reservoir) and lowest (16) in Klíčava (smallest reservoir). Our observation confirms a general increase of fish diversity with the area, volume and catchment size of a water body (Mehner et al., 2005). However, the number of taxa in individual samples was much lower, typically in single units. This confirms the observation from previous studies that eDNA is not homogeneously distributed in lentic habitats and reflects local species presence (Harper et al., 2019a; Lawson Handley et al., 2019; Li et al., 2019b). We observed greater taxon detection in autumn compared to summer, which may be due to prolonged eDNA persistence at colder temperatures (Collins et al., 2018; Lawson Handley et al., 2019). Summer sampling is more likely to reflect contemporary species distribution and activity compared to colder conditions that preserve eDNA and facilitate transport, and could provide more accurate information on changes in species activity (e.g. downstream migration for wintering, Jonsson \& Gravem, 1985) as well as eDNA flushed from upstream. These results provide further evidence that spatial and temporal replication in eDNA surveys is required for reliable estimates of species richness (de Souza et al., 2016; Djurhuus et al., 2020; Hänfling et al., 2016; Lawson-Handley et al., 2019; Li et al., 2019b).

Despite this spatiotemporal heterogeneity, we found semi-quantitative abundance estimates from eDNA 
metabarcoding in reservoirs (i.e. site occupancy) were highly correlated with abundance categories based on long-term fish surveys, which corroborates previous studies in UK lakes (Hänfling et al., 2016; Lawson Handley et al., 2019). The majority of fish in our studied reservoirs were of riverine origin, but the most plastic species, such as freshwater bream and roach, prevailed and occupied new niches of more or less standing water (Blabolil et al., 2016). Although the pelagic zone was more homogeneous compared to the structured littoral zone with different bottom substrate, vegetation, slope, Bray-Curtis dissimilarity values were lower (indicating higher similarity) for littoral samples compared to pelagic samples. This may be due to the lower number of taxa per sample in pelagic habitats resulting in more dissimilar samples. Studies in other geographic regions also found more species in the littoral compared to the pelagic zone (Lawson Handley et al., 2019; Zhang et al., 2019). Overall, more taxa per sample resulted in higher similarity as shown in tributary samples.

\section{Environmental correlates of fish distribution}

Interpretation of eDNA-based results is not straightforward as eDNA dynamics, including deposition, accumulation, transport, and fate, and fish distribution are influenced by biological and environmental variables (Barnes et al., 2014; de Souza et al., 2016; Mehner et al., 2005). In heterogeneous environments, hydrodynamics affecting water movements should be taken into account. Flow in lotic environments, such as rivers or brooks, combines eDNA of local residents with eDNA being transported from upstream (Jane et al., 2015; Pont et al., 2018). Flow is also present in reservoirs and most likely explains the combined detection of taxa associated with running water and upstream standing waters as well as the high diversity found in the main inflows of the study reservoirs. For example, detection of common carp and topmouth gudgeon in running water may have been due to eDNA transport from commercial ponds in the catchment, although escaped fish from these locations could also explain the eDNA signal in rivers. Downstream eDNA transport of eDNA was further supported by the negative correlation with normalised water age for some taxa. In contrast, a positive correlation with normalised water age reflects species' preference for a particular habitat and lentic conditions, e.g. prussian carp and European bitterling (Kottelat \& Freyhof, 2007).

Wind and wave action can also create currents in lentic environments that transport eDNA (Moyer et al., 2014). This effect is more pronounced in summer, with strong thermal stratification separating layers of different temperatures and densities. In this study, species associated with reservoir bottoms, such as European eel, stone loach and barbel (Barbus barbus), were detected only in littoral habitats. One exception is ruffe, the most common species associated with the benthos in the studied reservoirs that has a pelagic juvenile phase before settlement on the bottom (Jůza et al., 2015). Ruffe detection in both habitats can be explained by potential horizontal currents as well as eDNA shed by juveniles. Nonetheless, horizontal eDNA transport could prove useful to detect different ontogenetic phases of a species with eDNA metabarcoding if they utilise distinct habitats (Zhang et al., 2019).

Despite eDNA transport facilitated by flow, wind, and wave action in reservoirs, eDNA signals for different taxa were spatially structured and reflected species' ecological niches. Spatial distribution of fishes in heterogeneous freshwater bodies can result from various environmental factors individually or combined, but the most important factor is temperature. Higher temperature stimulates metabolic and behavioural activity of most poikilotherm fish (Stoner, 2004), which can also increase eDNA release and deposition by fish into environment as they exhibit greater rates of movement, feeding, digestion, and excretion (Jo et al., 2019; Robson et al., 2016). More active fish may have higher eDNA detection probabilities; however, warmer water temperature is also associated with greater UV irradiation, greater microbial activity (including feeding on eDNA as a dissolved organic phosphorus substrate), and reduced oxygen solubility (Barnes et al., 2014; Collins et al., 2018; Scharfenberger et al., 2019). All of these factors contribute to eDNA degradation and subsequently lower detection probabilities (Jo et al., 2019; Tsuji et al., 2017).

Species classed as cold water were detected in late autumn, mostly in tributary parts of the reservoirs. Specifically, coldwater salmonids were detected in running waters as expected due to higher water temperature at the surface and low DO concentrations in the colder, lower layers of standing water. eDNA accumulation in deep hypolimnetic water was not supported by our data. Species typically associated with deep open water, 
such as Coregonus spp., are naturally missing in artificial water bodies and where stocked, their presence is often restricted by lack of DO during summer stratification (Kottelat \& Freyhof, 2007). The effects of DO and locality are further masked by tight correlations with temperature, trophic status and water age. For robust statistical analyses, more seasons and an equal number of habitats should be sampled. We selected two contrasting seasons and the number of habitats was derived by each reservoir's morphology to achieve a reasonable compromise between investigator effort and information gained.

In our study, fish communities in canyon-shaped reservoirs were heavily driven by trophic status along the longitudinal gradient. The proxy of total ChlA concentration was positively correlated with temperature, and species associated with warmer water were detected in samples with higher trophic status. European eel was the only species strongly associated with trophic status independent of temperature. This species is an ambush predator, often with nocturnal activity (Trancart et al., 2019), and so may benefit from the dense water blooms and artificial darkness created by high trophic status. Community composition and distribution of particular species were found to change in response to trophic status in freshwater (Lawson Handley et al., 2018) and marine (Djurhuus et al., 2020) systems using eDNA metabarcoding. These findings and our own provide evidence that eDNA metabarcoding can be used to understand shifts in communities in response to environmental gradients.

\section{Conclusion}

Robust data are necessary to assess and improve ecological status. Conventional methods are usually invasive or even destructive. To increase the use of novel non-invasive methods, validation is necessary. This study demonstrated that eDNA metabarcoding can provide valuable data for ecological interpretation. The synthesis of eDNA-based data with environmental data measured by mobile multiparameter devices has great potential to substitute conventional fish monitoring. Moreover, a combined analysis of both data types is suitable for addressing fundamental ecological questions. This research has contributed to a better understanding of eDNA dynamics and will motivate stakeholders for broader application. The application of eDNA metabarcoding for biomonitoring in heterogeneous ecosystems is a huge step forward to reach high quality data with a non-invasive method that is worthy of the $21^{\text {st }}$ century.

\section{Acknowledgments}

Thanks are given to Vltava River Authority for enabling the fieldwork, colleagues from FishEcU (www.fishecu.cz) for help in the field and expert judgment, Jiří Jarošík and Allan Souza for help with the graphical presentation. This study was supported by the project QK1920011 "Methodology of predatory fish quantification in drinking-water reservoirs to optimize the management of aquatic ecosystems", MSM200961901 ,The true picture of eDNA“, ERDF/ESF project "Biomanipulation as a tool for improving water quality of dam reservoirs" (No. CZ.02.1.01/0.0/0.0/16_025/0007417) and by the CAS within the program of the Strategy AV 21 (VP21).

\section{Author Contributions}

PB, TJ, MV, ZS, PR, PZ and JP participated in the field work. PB, LH, ŠR, GS and CM participated in the laboratory work. PB, JP and $\mathrm{BH}$ designed the study. $\mathrm{PB}, \mathrm{LH}$ and $\mathrm{JH}$ conducted the data analysis. PB wrote the first draft. All authors contributed substantial feedback during manuscript preparation. The authors declare no conflict of interest.

\section{Data Accessibility}

DNA sequences: The de-novo sequences were uploaded to Genbank, asp accession numbers MT163435, MT163450, MT163449 and marena whitefish accession numbers MT163451, MT163458, MT163460. For each PCR product, a FASTQ file comprising all raw reads is archived in NCBI Sequence Read Archive under accession number PRJNA611963.

\section{References}


Alberdi, A., Aizpurua, O., Gilbert, M. T. P., \& Bohmann, K. (2018). Scrutinizing key steps for reliable metabarcoding of environmental samples. Methods in Ecology and Evolution , 9, 134-147. doi: 10.1111/2041210X.12849

Balasingham, K. D., Walter, R. P., Mandrak, N. E., \& Heath, D. D. (2017). Environmental DNA detection of rare and invasive fish species in two Great Lakes tributaries. Molecular Ecology , 27, 112-127. doi: $10.1111 /$ mec. 14395

Baran, R., Jůza, T., Tušer, M., Balk, H., Blabolil, P., Čech, M., ... Kubečka, J. (2017). A novel upward-looking hydroacoustic method for improving pelagic fish surveys. Scientific Reports , 7, 4823. doi: 10.1038/s41598-017-04953-6

Barnes, M. A., Turner, C. R., Jerde, C. L., Renshaw, M. A., Lindsay Chadderton, W., \& Lodge, D. M. (2014). Environmental Conditions Influence eDNA Persistence in Aquatic Systems. Environmental Science E Technology , 48, 1819-1827. doi: 10.1021/es404734p

Baron, J. S., LeRoy Poff, N., Angermeier, P. L., Dahm, C. N., Gleick, P. H., Hairston, N. G., ... Steinman, A. D. (2002). Meeting ecological and societal needs for freshwater. Ecological Applications , 12, 1242-1260. doi: 10.1890/1051-0761(2002)012[1247:MEASNF]2.0.CO;2

Blabolil, P., Logez, M., Ricard, D., Prchalová, M., Ríha, M., Sagouis, A., ... Argillier, C. (2016). An assessment of the ecological potential of Central and Western European reservoirs based on fish communities. Fisheries Research , 173, 80-87. doi: 10.1016/j.fishres.2015.05.022

Blabolil, P., Boukal, D.S., Ricard, D., Kubečka, J., Ř́ha, M., Vašek, M., .. Peterka, J. (2017a). Optimal gillnet sampling design for the estimation of fish community indicators in heterogeneous freshwater ecosystems. Ecological Indicators , 77, 368-376. doi: 10.1016/j.ecolind.2017.02.036

Blabolil, P., Ř́íha, M., Ricard, D., Peterka, J., Prchalová, M., Vašek, M., .. Kubečka, J. (2017b). A simple fish-based approach to assess the ecological quality of freshwater reservoirs in Central Europe.Knowledge and Management of Aquatic Ecosystems , 2017-1, 418. doi: 10.1051/kmae $/ 2017043$

Blabolil, P., Duras, J., Jůza, T., Kočvara, L., Matěna, J., Muška, M., .. P Peterka, J. (2018). Assessment of burbot (Lota lota) population sustainability in temperate reservoir. Journal of Fish Biology , 92: 1545-1559. doi: $10.1111 / \mathrm{jfb} .13610$

Bolger, A. M., Lohse, M., \& Usadel, B. (2014). Trimmomatic: a flexible trimmer for Illumina sequence data. Bioinformatics . 30, 2114-2120. doi: 10.1093/bioinformatics/btu170

Boukal, D. S., Jankovský, M., Kubečka, J., \& Heino, M. (2012). Stock-catch analysis of carp recreational fisheries in Czech reservoirs: insights into fish survival, water body productivity and impact of extreme events. Fisheries Research , 119-120: 23-32. doi: 10.1016/j.fishres.2011.12.003

Bronner, I. F., Quail, M. A., Turner, D. J., \& Swerdlow, H. (2014). Improved Protocols for Illumina Sequencing. Current Protocols in Human Genetics, 18.2.1-18.2.42. doi: 10.1002/0471142905.hg1802s80

Bylemans, J., Gleeson, D. M., Duncan, R. P., Hardy, C. M., \& Furlan, E. M. (2019). A performance evaluation of targeted eDNA and eDNA metabarcoding analyses for freshwater fishes. Environmental DNA , 1, 402-414. doi: 10.1002/edn3.41

Collins, R.A., Wangensteen, O.S., O'Gorman, E.J., Mariani, S., Sims, D.W. \& Genner, M.J. (2018). Persistence of environmental DNA in marine systems. Communications biology , 1, 185. doi: 10.1038/s42003-0180192-6

de Souza, L. S., Godwin, J. C., Renshaw, M. A., \& Larson, E. (2016). Environmental DNA (eDNA) detection probability is influenced by seasonal activity of organisms. PLoS One 11, e0165273. doi: 10.1371/journal.pone. 0165273 
Deiner, K., Fronhofer, E. A., Mächler, E., Walser, J.-C., \& Altermatt, F. (2016). Environmental DNA reveals that rivers are conveyor belts of biodiversity information. Nature Communications , 7, 12544. doi: $10.1038 /$ ncomms 12544 .

Deiner, K., Bik, H. M., Mächler, E., Seymour, M., Lacoursière-Roussel, A., Altermatt, F., ... Bernatchez, L. (2017). Environmental DNA metabarcoding: Transforming how we survey animal and plant communities.Molecular Ecology , 26, 5872-5895. doi: 10.1111/mec.14350

Delrieu-Trottin, E., Williams, J. T., Pitassy, D., Driskell, A., Hubert, N., Viviani, J., . . Planes, S. (2019). A DNA barcode reference library of French Polynesian shore fishes. Scientific data, 6, 114. doi: 10.1038/s41597019-0123-5

Djurhuus, A., Closek, C. J., Kelly, R. P., Pitz, K. J., Michisaki, R. P., Starks, H. A., .. Breitbart, M. (2020). Environmental DNA reveals seasonal shifts and potential interactions in a marine community. Nature Communications , 11, 254. doi: 10.1038/s41467-019-14105-1

EC, 2000. European Commision: Directive 2000/60/EC of the European Parliament and of the Council of 23 October 2000 establishing a framework for Community action in the field of water policy. Official Journal of the European Parliament, L327, 1-82.

Ford, D. E. (1990). Reservoir inflow processes. In: K. W. Thornton, B. Kimmel \& F. E. Pazne (Eds.), Reservoir Limnology: Ecological Perspectives (pp. 15-42), Wiley, New York.

Furlan, E. M., Gleeson, D., Wisniewski, C., Yick, J., \& Duncan, R. P. (2019). eDNA surveys to detect species at very low densities: A case study of European carp eradication in Tasmania, Australia. Journal of Applied Ecology . 56, 2505-2517. doi: 10.1111/1365-2664.13485

Hänfling, B., Lawson Handley, L., Read, D. S., Hahn, C., Li, J., Nichols, P., ... Winfield, I. J. (2016). Environmental DNA metabarcoding of lake fish communities reflects long-term data from established survey methods. Molecular Ecology , 25, 3101-3119. doi: 10.1111/mec.13660

Harper, L. R., Griffiths, N. P., Lawson Handley, L., Sayer, C. D., Read, D. S., Harper, K. J., ... Hänfling, B. (2019a). Development and application of environmental DNA surveillance for the threatened crucian carp (Carassius carassius ). Freshwater Biology , 64, 93-107. doi: 10.1111/fwb.13197

Harper, L. R., Lawson Handley, L., Hahn, C., Boonham, N., Rees, H. C., Lewis, E., .. Hänfling, B. (2019b). Generating and testing ecological hypotheses at the pondscape with environmental DNA metabarcoding: A case study on a threatened amphibian.Environmental DNA , 00, 1-16. doi: 10.1002/edn3.57

Hering, D., Borja, A., Jones, J. I., Pont, D., Boets, P., Bouchez, A., .. Kelly, M. (2018). Implementation options for DNA-based identification into ecological status assessment under the European Water Framework Directive. Water Research , 138, 192-205. doi: 10.1016/j.watres.2018.03.003

Holubová, M., Čech, M., Vašek, M., \& Peterka, J. (2019). On the use of a visual census in surveying fish communities in lentic water bodies.Ecological Indicators . 105, 1-5. doi: 10.1016/j.ecolind.2019.05.042

Huson, D. H., Auch, A. F., Qi, J., \& Schuster, S. C. (2007). MEGAN analysis of metagenomic data. Genome Research , 17(3), 377-386. doi: 10.1101/gr.5969107

Jane, S. F., Wilcox, T. M., McKelvey, K. S., Young, M. K., Schwartz, M. K., Lowe, W. H., ... Whiteley, A. R. (2015). Distance, flow and PCR inhibition: eDNA dynamics in two headwater streams. Molecular Ecology Resources , 15, 216-227. doi: 10.1111/1755-0998.12285

Jonsson, B., \& Gravem, F. R. (1985). Use of space and food by resident and migrant brown trout, Salmo trutta . Environmental Biology of Fishes, 14, 281-293. doi: 10.1007/BF00002633

Jeunen, G. J., Knapp, M., Spencer, H. G., Lamare, M. D., Taylor, H. R., Stat, M., .. Gemmell, M. J. (2019). Environmental DNA (eDNA) metabarcoding reveals strong discrimination among diverse marine habitats connected by water movement. Molecular Ecology Resources , 19, 426-438. doi: 10.1111/1755-0998.12982 
Jo, T., Murakami, H., Yamamoto, S., Masuda, R. \& Minamoto, T. (2019) Effect of water temperature and fish biomass on environmental DNA shedding, degradation, and size distribution. Ecology and evolution, 9, 1135-1146. doi: 10.1002/ece3.4802

Jůza, T., Ricard, D., Blabolil, P., Čech, M., Draštík, V., Frouzová, J., .. Kubečka, J. (2015). Speciesspecific gradients of juvenile fish density and size in pelagic areas of temperate reservoirs.Hydrobiologia , 762: 169-181. doi: 10.1007/s10750-015-2346-6

Kelly, R. P., Shelton, A. O., \& Gallego, R. (2019). Understanding PCR processes to draw meaningful conclusions from environmental DNA studies.Scientific Reports , 9, 1-14. doi: 10.1038/s41598-019-48546-x

Kottelat, M., \& Freyhof, J. (2007) Handbook of European freshwater fishes. Kottelat, Cornol. doi: $10.1007 / \mathrm{s} 10228-007-0012-3$

Kubečka, J., Hohausová, E., Matěna, J., Peterka, J., Amarasinghe, U. S., Bonar, S. A., .. Winfield, I. J. (2009). The true picture of a lake or reservoir fish stock: A review of needs and progress. Fisheries Research , 96, 1-5. doi: 10.1016/j.fishres.2008.09.021

Labadie, J. W. (2004). Optimal Operation of Multireservoir Systems: State-of-the-Art Review. Journal of Water Resources Planning and Management , 130, 93-111. doi: 10.1061/(ASCE)0733-9496(2004)130:2(93)

Lacoursière-Roussel, A., Côté, G., Leclerc, V., \& Bernatchez, L. (2016). Quantifying relative fish abundance with eDNA: a promising tool for fisheries management. Journal of Applied Ecology , 53, 1148-1157. doi: $10.1111 / 1365-2664.12598$

Lawson Handley, L. (2015). How will the 'molecular revolution' contribute to biological recording? Biological Journal of the Linnean Society , 115, 750-766. doi: 10.1111/bij.12516

Lawson Handley, L., Read, D. S., Winfield, I. J., Kimbell, H., Johnson, H., Li, J., . . Hänfling, B. (2019). Temporal and spatial variation in distribution of fish environmental DNA in England's largest lake.Environmental DNA , 1, 26-39. doi: 10.1002/edn3.5

Li, J., Hatton-Ellis, T. W., Lawson Handley, L., Kimbell, H. S., Benucci, M., Peirson, G., \& Hanfling, B. (2019a). Ground-truthing of a fish-based environmental DNA metabarcoding method for assessing the quality of lakes. Journal of Applied Ecology , 56, 1232-1244. doi: 10.1111/1365-2664.13352

Li, J., Lawson Handley, L., Harper, L. R., Brys, R., Watson, H. V., Di Muri, C., ... Hanfling, B. (2019b). Limited dispersion and quick degradation of environmental DNA in fish ponds inferred by metabarcoding. Environmental DNA . 1, 238-250. doi: 10.1002/edn3.24

Lusk, S., Hanel, L., Lojkasek, B., Luskova, V., \& Muška, M. (2017). The Red List of lampreys and fishes of the Czech Republic. In: Chobot, K., \& Němec, M. (Eds.), Red List of threatened species of the Czech Republic vertebrates. Př́roda, 34, (pp. 51-82), Nature Conservation Agency of the Czech Republic, Prague.

Magoč, T., \& Salzberg, S. L. (2011). FLASH: fast length adjustment of short reads to improve genome assemblies. Bioinformatics , 27, 2957-2963. doi: 10.1093/bioinformatics/btr507

McDevitt, A. D., Sales, N. G., Browett, S. S., Sparnenn, A. O., Mariani, S., Wangensteen, O. S., ... Benvenuto C. (2019). Environmental DNA metabarcoding as an effective and rapid tool for fish monitoring in canals. Journal of Fish Biology , 95, 679-682. doi: 10.1111/jfb.14053

Mehner, T., Diekmann, M., Brämick, U., \& Lemcke, R. (2005). Composition of fish communities in German lakes as related to lake morphology, trophic state, shore structure and human-use intensity. Freshwater Biology , 50, 70-85. doi: 10.1111/j.1365-2427.2004.01294.x

Miya, M., Sato, Y., Fukunaga, T., Sado, T., Poulsen, J. Y., Sato, K., ... Iwasaki, W. (2015). MiFish, a set of universal PCR primers for metabarcoding environmental DNA from fishes: detection of more than 230 subtropical marine species. Royal Society Open Science, 2, 150088. doi: 10.1098/rsos.150088 
Monsen, N. E., Cloern, J. E., Lucas, L. V., \& Monismith, S. G. (2002). The use of flushing time, residence time, and age as transport time scales. Limnology and Oceanography , 47, 1545-1553. doi: 10.4319/lo.2002.47.5.1545

Moyer, G. R.,, Díaz-Ferguson, E., Hill, J. E., \& Shea, C. (2014). Assessing environmental DNA detection in controlled lentic systems.PLoS One 9, e103767. doi: 10.1371/journal.pone.0103767

Naylor, R. L., Williams, S. L., Strong, D. R. (2001). Aquaculture-A gateway for exotic species. Science . 294, 1655-1656. doi: 10.1126/science.1064875

Nicholson, A., McIsaac, D., MacDonald, C., Gec, P., Mason, B. E., Rein, W., ... Hanner, R. H. (2020) An analysis of metadata reporting in freshwater environmental DNA research calls for the development of best practice guidelines. Environmental DNA . doi: 10.1002/edn3.81

Oksanen, J., Blanchet, F. G., Friendly, M., Kindt, R., Legendre, P., McGlinn, D., .. Wagner, H. (2019). vegan: Community Ecology Package. $R$ package version 2.5-6 .

Olds, B. P., Jerde, C. L., Renshaw, M. A., Li, Y., Evans, N. T., Turner, C. R., .. Lamberti, G. A. (2016). Estimating species richness using environmental DNA. Ecology and Evolution , 16, 4214-4226. doi: $10.1002 /$ ece 3.2186

Pergl, J., Sádlo, J., Petrusek, A., Laštůvka, Z., Musil, J., Perglová, I., ... Pyšek, P. (2016). Black, Grey and Watch Lists of alien species in the Czech Republic based on environmental impacts and management strategy. NeoBiota , 28, 1-37. doi: 10.3897/neobiota.28.4824

Pont, D., Rocle, M., Valentini, A., Civade, R., Jean, P., Maire, A., .. Dejean, T. (2018). Environmental DNA reveals quantitative patterns of fish biodiversity in large rivers despite its downstream transportation. Scientific Reports , 8, 10361. doi: 10.1038/s41598-018-28424-8

Prchalová, M., Kubečka, J., Čech, M., Frouzová, J., Draštík, V., Hohausová, E., .. Vašek, M. (2009a). The effect of depth, distance from dam and habitat on spatial distribution of fish in an artificial reservoir. Ecology of Freshwater Fish , 18, 247-260. doi: 10.1111/j.1600-0633.2008.00342.x

Prchalová, M., Kubečka, J., Ř́ha, M., Mrkvička, T., Vašek, M., Jůza, T., .. Křížek, J. (2009b). Size selectivity of standardized multimesh gillnets in sampling coarse Europen species. Fisheries Research , 96, 51-57. doi: 10.1016/j.fishres.2008.09.017

R Development Core Team, 2020. R: A Language and Environment for Statistical Computing. R Foundation for Statistical Computing.

Riaz, T, Shehzad W, Viari, A, Pompanon, F., Taberlet, P., \& Coissac, P. (2011). ecoPrimers: inference of new DNA barcode markers from whole genome sequence analysis. Nucleic Acids Research, 39, e145. doi: 10.1093/nar/gkr732

Ř́ha, M., Kubečka, J., Mrkvička, T., Prchalová, M., Čech, M., Draštík, V., .. Vašek M. (2008). Dependence of beach seine net efficiency on net length and diel period. Aquatic Living Resources , 21, 411-418. doi: 10.1051/alr:2008061

Ř́ha, M., Ricard, D., Vašek, M., Prchalová, M., Mrkvička, T., Jůza, T., ... Kubečka, J. (2015). Patterns in diel habitat use of fish covering the littoral and pelagic zones in a reservoir.Hydrobiologia , 747, 111-131. doi: $10.1007 / \mathrm{s} 10750-014-2124-\mathrm{x}$

Robinson, V. C., Garcia de Leaniz, C., Rolla, M., \& Consuegra, S. (2019). Monitoring the eradication of the highly invasive topmouth gudgeon (Pseudorasbora parva) using a novel eDNA assay. Environmental DNA . 1, 74-85. doi: $10.1002 /$ edn3.12

Robson, H. L. A., Noble, T. H., Saunders, R. J., Robson, S. K. A., Burrows, D. W., \& Jerry, D. R. (2016). Fine-tuning for the tropics: application of eDNA technology for invasive fish detection in tropical freshwater ecosystems. Molecular Ecology Resources . 16. 922-932. doi: 10.1111/1755-0998.12505 
Ruppert, K. M., Kline, R. J., \& Rahman, M. S. (2019). Past, present, and future perspectives of environmental DNA (eDNA) metabarcoding: A systematic review in methods, monitoring, and applications of global eDNA. Global Ecology and Conservation , 17, e00547. doi: 10.1016/j.gecco.2019.e00547

Rychtecký, P., \& Znachor, P. (2011). Spatial heterogeneity and seasonal succession of phytoplankton along the longitudinal gradient in a eutrophic reservoir. Hydrobiologia , 663, 175-186. doi: 10.1007/s10750-0100571-6

Scharfenberger, U., Jeppesen, E., Beklioğlu, M., Søndergaard, M., Angeler, D. G., Çakıroğlu, A. İ., ... Adrian, R. (2019). Effects of trophic status, water level, and temperature on shallow lake metabolism and metabolic balance: A standardized pan-European mesocosm experiment.Limnology and Oceanography , 64, 616-631. doi: 10.1002/lno.11064

Sellers, G. S., Di Muri, C., Gómez, A., \& Hänfling, B. (2018). Mu-DNA: a modular universal DNA extraction method adaptable for a wide range of sample types. Metabarcoding and Metagenomics, 2, e24556. doi: 10.17605/OSF.IO/VRB4A

Šmejkal, M., Prchalová, M., Čech, M., Vašek, M., Ř́íha, M., Jůza, T., .. Kubečka, J. (2014). Associations of fish with various types of littoral habitats in reservoirs. Ecology of Freshwater Fish , 23, 405-413. doi: 10.1071/MF15361

Šmilauer, P., \& Lepš, J. (2014). Multivariate Analysis of Ecological Data Using CANOCO 5 . Cambridge University Press. doi: 10.1017/CBO9781139627061

Stoner, A. W. (2004). Effects of environmental variables on fish feeding ecology: Implications for the performance of baited fishing gear and stock assessment. Journal of Fish Biology , 65, 1445-1471. doi: 10.1111/j.0022-1112.2004.00593.x

Straškraba, M. (2005). Reservoirs and Other Artificial Water Bodies. In: P. OSullivan \& C. Reynolds, (Eds.). The Lakes Handbook, Volume 2 (pp. 300-327). Oxford, UK: Blackwell Science Ltd.

Straškrabová, V., Hejzlar, J., Procházková, L., \& Vyhnálek, V. (1994). Eutrophication in stratified deep reservoirs. Water Science and Technology , 30, 273-279. doi: 10.2166/wst.1994.0537

Straškrabová V., \& Pivnička K. (2001). The Kličava Reservoir - Hydrobiological and Ichthyological studies (1965-2000) . Acta Universitatis Carolinae, Environmentalica.

Taberlet, P., Bonin, A., Zinger, L., \& Coissac, E. (2018).Environmental DNA . 1st ed. Oxford: Oxford University Press. doi: 10.1093/oso/9780198767220.001.0001

Thornton, K. W., Kimmel, B. L., \& Payne F. E. (1990). Reservoir Limnology: Ecological Perspectives . Willey, New York.

Trancart, T., Carpentier, A., Acou, A., Danet, V., Elliott, S., \& Feunteun E. (2019). Behaviour of endangered European eels in proximity to a dam during downstream migration: Novel insights using high accuracy 3D acoustic telemetry. Ecology of Freshwater Fish . 29, 266-279. doi: 10.1111/eff.12512

Tsuji, S., Ushio, M., Sakurai, S., Minamoto, T. \& Yamanaka, H. (2017) Water temperature-dependent degradation of environmental DNA and its relation to bacterial abundance. PloS One, 12, e0176608. doi: 10.1371/journal.pone.0176608

Valentini, A., Taberlet, P., Miaud, C., Civade, R., Herder, J., Thomsen, P. F., ... Dejean, T. (2016). Nextgeneration monitoring of aquatic biodiversity using environmental DNA metabarcoding. Molecular Ecology , 25, 929-942. doi: 10.1111/mec.13428

Vašek, M., Prchalová, M., Peterka, J., Ketelaars, H. A. M., Wagenvoort, A. J., Čech, M., ... Kubečka, J. (2013). The utility of predatory fish in biomanipulation of deep reservoirs. Ecological Engineering , 52: 104-111. doi: $10.1016 / j$.ecoleng.2012.12.100 
Veǰrík, L., Vejř́ková, I., Kočvara, L., Blabolil, P., Peterka, J., Sajdlová, Z., .. Čech M. (2019). The pros and cons of the invasive freshwater apex predator, European catfish Silurus glanis, and powerful angling technique for its population control. Journal of Environmental Management, 241, 374-382. doi: 10.1016/j.jenvman.2019.04.005

Wells, S. A. (2019). CE-QUAL-W2: A two-dimensional, laterally averaged, hydro-dynamic and water quality model, version 4.2 .:User manual. Department of Civil and Environmental Engineering, Portland State University, Portland, OR.

Wetzel, R. G. (2001). Limnology: Lake and River Ecosystems . 3rd Edition. Academic Press . doi: 10.1016/C2009-0-02112-6

Zhang, Z., Schwartz, S., Wagner, L., \& Miller, W. (2000). A greedy algorithm for aligning DNA sequences. Journal of Computational Biology , 7, 203-214. doi: 10.1089/10665270050081478

Zhang, S., Lu, Q., Wang, Y., Wang, X., Zhao, J., \& Yao, M. (2019). Assessment of fish communities using environmental DNA: Effect of spatial sampling design in lentic systems of different sizes. Molecular Ecology Resources . 20, 242-255. doi: 10.1111/1755-0998.13105

Znachor, P., Nedoma, J., Hejzlar, J., Seďa, J., Komárková, J., Koláŕ, V., .. B Boukal, D. S. (2020). Changing environmental conditions underpin long-term patterns of phytoplankton in a freshwater reservoirScience of the Total Environment , 710, 135626. doi: 10.1016/j.scitotenv.2019.135626

\section{Hosted file}

Table1.docx available at https://authorea.com/users/335544/articles/461427-environmentaldna-metabarcoding-uncovers-environmental-correlates-of-fish-communities-in-spatiallyheterogeneous-freshwater-habitats

\section{Hosted file}

Table2.docx available at https://authorea.com/users/335544/articles/461427-environmentaldna-metabarcoding-uncovers-environmental-correlates-of-fish-communities-in-spatiallyheterogeneous-freshwater-habitats

\section{Hosted file}

Table3.docx available at https://authorea.com/users/335544/articles/461427-environmentaldna-metabarcoding-uncovers-environmental-correlates-of-fish-communities-in-spatiallyheterogeneous-freshwater-habitats

\section{Hosted file}

Table4.docx available at https://authorea.com/users/335544/articles/461427-environmentaldna-metabarcoding-uncovers-environmental-correlates-of-fish-communities-in-spatiallyheterogeneous-freshwater-habitats 

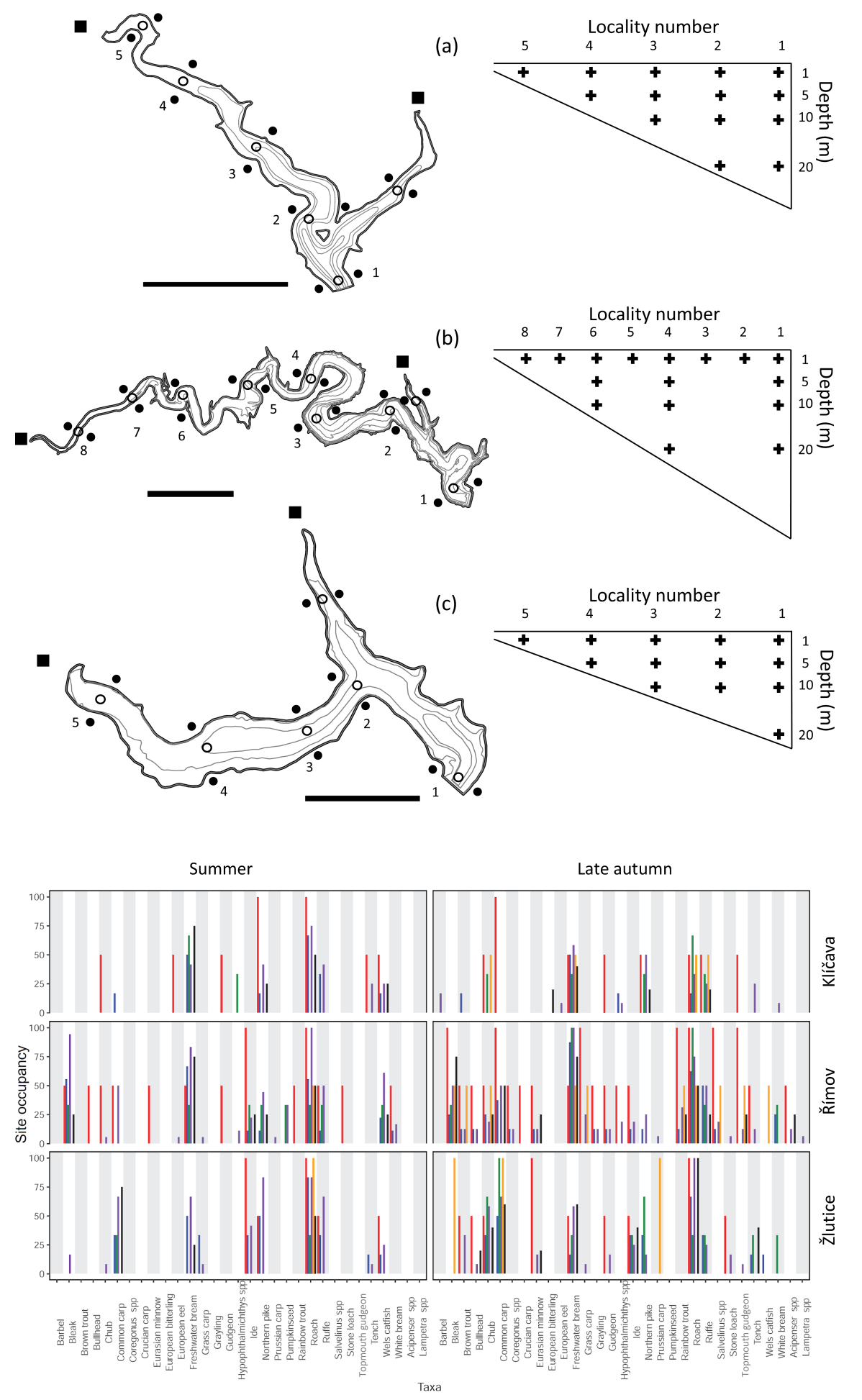


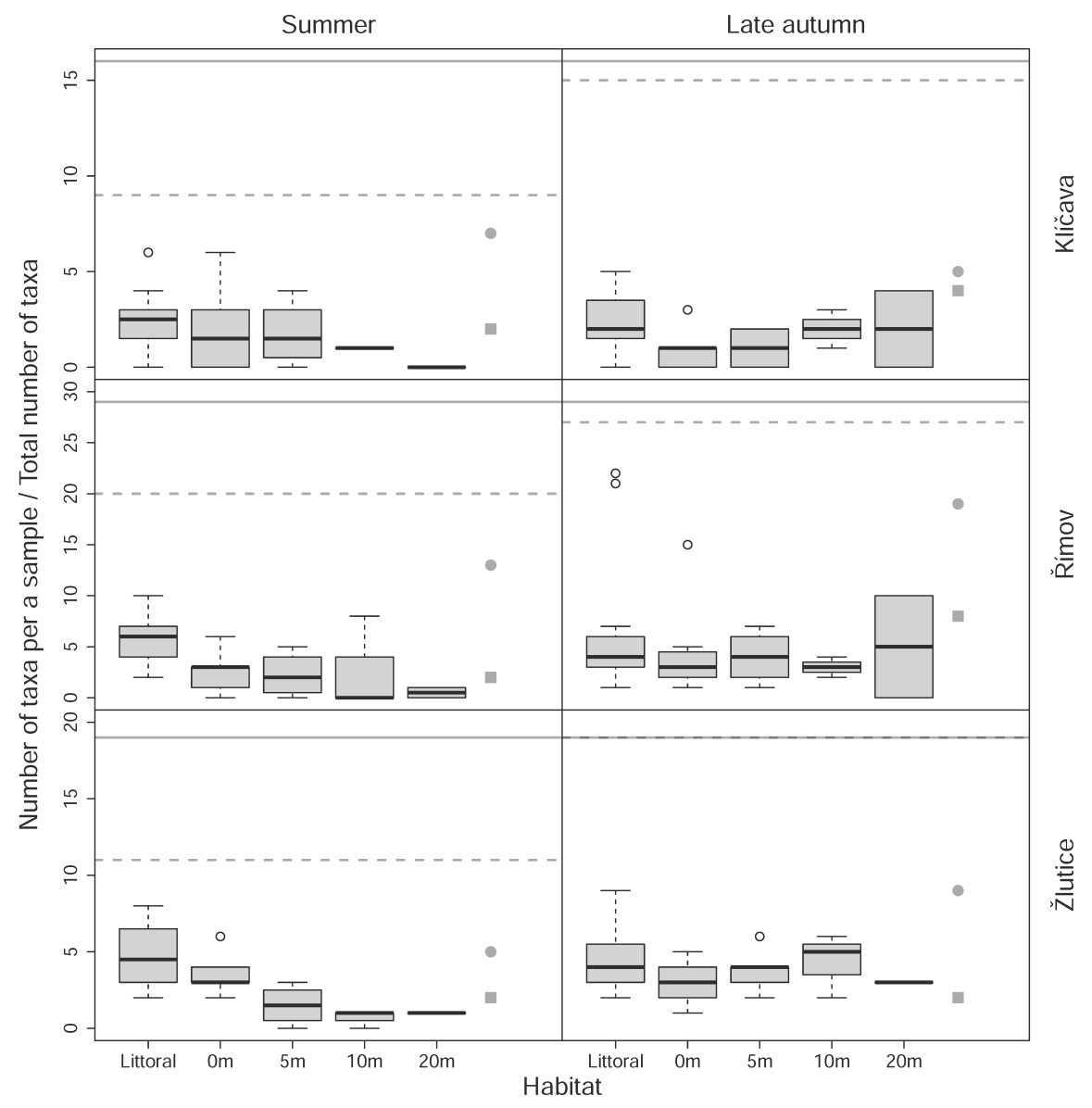




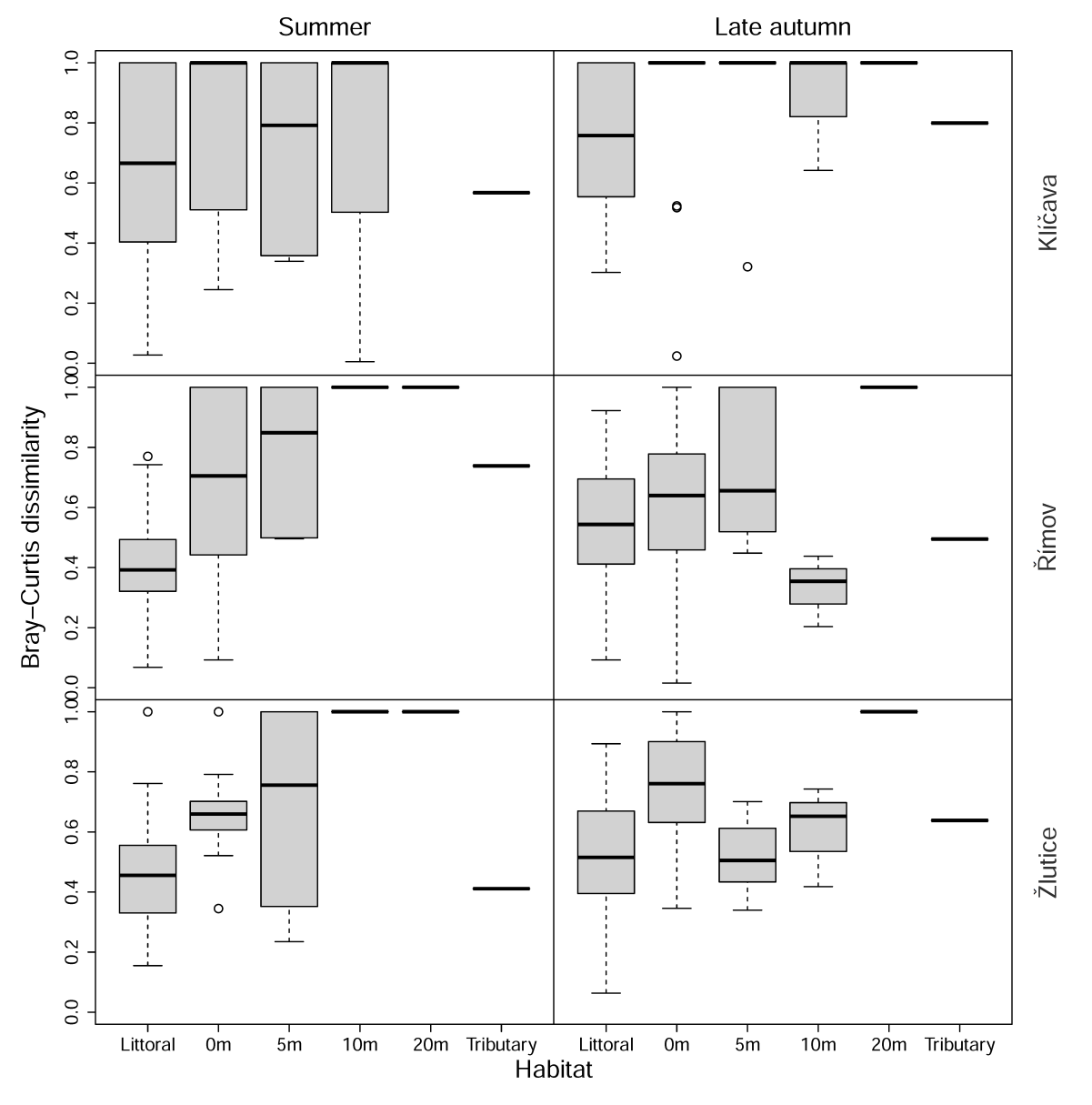




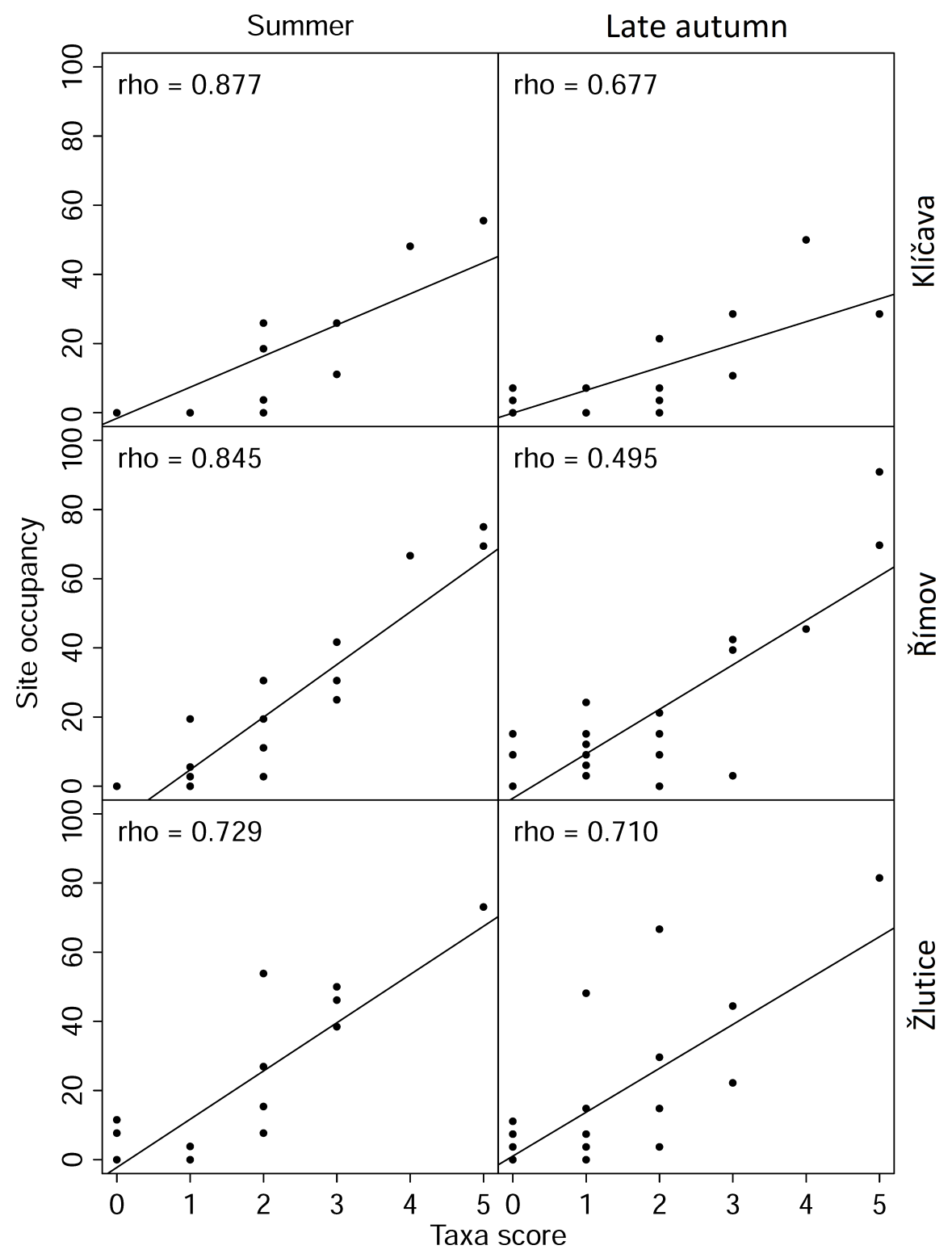



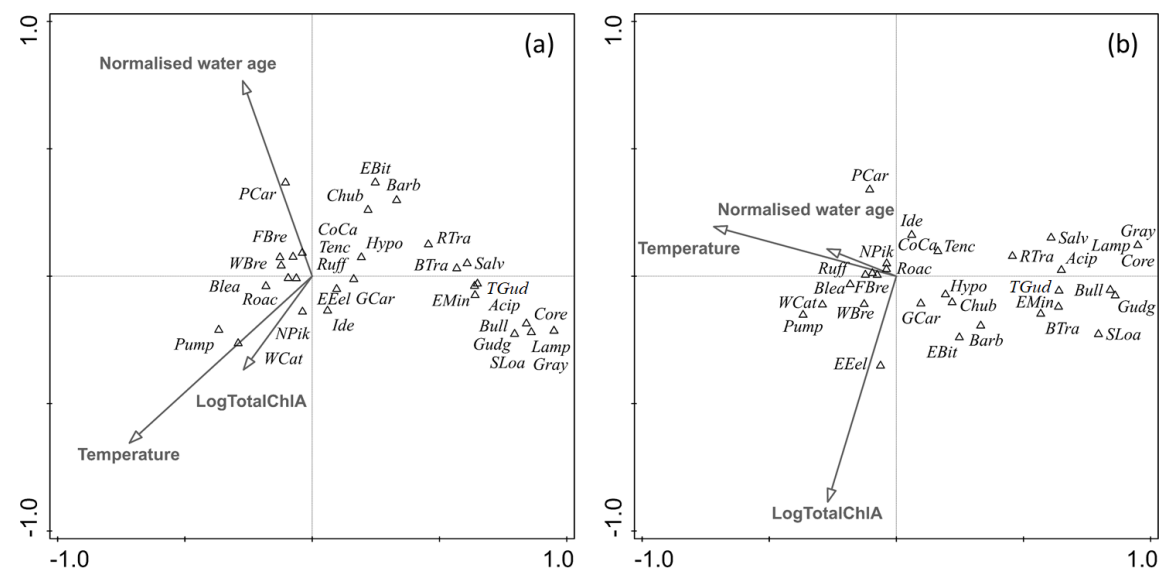